\section{Commentary: Early repair of complete atrioventricular septal defect is the forward move}

\author{
Joseph B. Clark, MD
}

For many congenital heart defects, there has been a progressive trend away from staged management and toward primary repair in infancy. For complete atrioventricular septal defect (cAVSD) repair, a target age of 3 to 6 months has broadly emerged, ${ }^{1}$ with some preferring even earlier. ${ }^{2}$ The reservation against early repair has been concern for a poor result with the left atrioventricular valve (LAVV) due to the fragile nature of the leaflets. If the reconstruction is unsatisfactory, options for replacement are limited and carry heightened risk. Nevertheless, when overt heart failure exhausts medical management, early surgery may sometimes become necessary.

In this issue of the Journal, Burrato and colleagues ${ }^{3}$ describe a large series of infants younger than 3 months of age with cAVSD who were managed with either complete repair or pulmonary artery banding (PAB) followed by delayed repair. While this study does not assess the optimal age of cAVSD repair, it offers another account of favorable outcomes achieved with early repair. The primary repair group demonstrated $3.3 \%$ early mortality and $92 \%$ survival and $78 \%$ freedom from LAVV reoperation at 10 years. The outcomes for 22 neonates were notable, with no early deaths and $100 \%$ survival and $75 \%$ freedom from LAVV reoperation at 10 years. Although this experience complements other singleinstitution series demonstrating positive outcomes for cAVSD repair at less than 3 months, ${ }^{2,4,5}$ these reports are

\footnotetext{
From the Division of Pediatric Cardiac Surgery, Department of Pediatrics, Penn State Children's Hospital, Hershey, Pa.

Disclosures: The author reported no conflicts of interest.

The Journal policy requires editors and reviewers to disclose conflicts of interest and to decline handling or reviewing manuscripts for which they may have a conflict of interest. The editors and reviewers of this article have no conflicts of interest.

Received for publication Aug 18, 2020; revisions received Aug 18, 2020; accepted for publication Aug 19, 2020; available ahead of print Aug 24, 2020.

Address for reprints: Joseph B. Clark, MD, 500 University Dr, H085, Hershey, PA 17033 (E-mail: jclark7@pennstatehealth.psu.edu).

J Thorac Cardiovasc Surg 2021;161:1602-3

$0022-5223 / \$ 36.00$

Copyright (c) 2020 by The American Association for Thoracic Surgery

https://doi.org/10.1016/j.jtcvs.2020.08.053
}

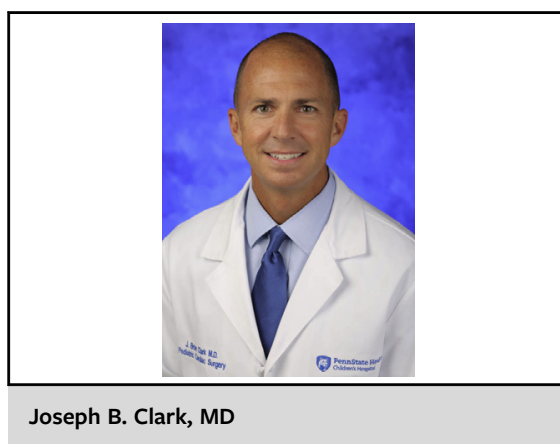

\author{
CENTRAL MESSAGE \\ For infants younger than \\ 3 months with complete \\ atrioventricular septal defect \\ who require early surgery due to \\ heart failure, primary repair \\ represents the preferred \\ strategy, even in neonates.
}

contrasted by a large, multicenter analysis showing increased morbidity and mortality for this population. ${ }^{1}$

The focus of the present study was to compare primary versus staged repair in young infants. While not a randomized controlled trial, the findings are persuasive: primary repair was associated with better survival than staged repair and similar freedom from LAVV reoperation. As the groups exhibited important differences including age, weight, and trisomy 21 prevalence, propensity score matching was performed and additionally corroborated the findings in favor of early repair. Accordingly, the authors have recommended primary repair as the preferred strategy.

The study has limitations. As a single-institution experience, the excellent outcomes with early repair may not be widely replicated. Also, despite propensity score matching, underlying selection bias may have exerted influence on the findings. Finally, the survival difference is attributable to a $19 \%$ interstage mortality for patients managed with $\mathrm{PAB}$, a rate consistent with historical series but worse than recent experience. In another multicenter study, 23 of 24 patients with PAB survived to cAVSD repair and demonstrated survival and freedom from LAVV reoperation similar to primary repair, thus supporting staged repair as a successful strategy. ${ }^{6}$ In his commentary, Alsoufi ${ }^{7}$ questioned whether PAB represented a retreating, backward move, but agreed that staging remains a prudent option for select patients. 
Both of these studies can be interpreted to support the choice for early cAVSD repair in young infants failing medical management. At the least, early repair represents a sound strategy with outcomes similar to staging; at the most, it represents a superior, one-operation strategy associated with improved outcomes. When faced with this challenging decision, this experience advocates for primary repair as the advancing, forward move, and invites and encourages increased pursuit of this strategy, even in neonates.

\section{References}

1. St Louis JD, Jodhka U, Jacobs JP, He X, Hill KD, Pasquali SK, et al. Contemporary outcomes of complete atrioventricular septal defect repair: analysis of the Society of Thoracic Surgeons congenital heart surgery database. J Thorac Cardiovasc Surg. 2014;148:2526-31.
2. Vida VL, Tessari C, Castaldi B, Padalino MA, Milanesi O, Gregori D, et al. Early correction of common atrioventricular septal defects: a single-center 20-year experience. Ann Thorac Surg. 2016;102:2044-51.

3. Burrato E, Hu T, Lui A, Wu D, d'Udekem Y, Brizard CP, et al. Early repair of complete atrioventricular septal defect has better survival than staged repair after pulmonary artery banding: a propensity score-matched study. J Thorac Cardiovasc Surg. 2021;161:1594-601.

4. Stephens EH, Ibrahimiye AN, Yerebakan H, Yilmaz B, Chelliah A, Levasseur S et al. Early complete atrioventricular canal repair yields outcomes equivalent to late repair. Ann Thorac Surg. 2015;99:2109-16.

5. Xie O, Brizard CP, d'Udekem Y, Galati JC, Kelly A, Yong MS, et al. Outcomes of repair of complete atrioventricular septal defect in the current era. Eur $J$ Cardiothorac Surg. 2014:45:610-7.

6. Devlin PJ, Jegatheeswaran A, McCrindle BW, Karamlou T, Blackstone EH Williams WG, et al. Pulmonary artery banding in complete atrioventricular septal defect. J Thorac Cardiovasc Surg. 2020;159:1493-503.

7. Alsoufi B. Commentary: pulmonary artery banding in infants with atrioventricular septal defect, valid strategy or backward move? J Thorac Cardiovasc Surg. 2020; 159:1504-6.

\section{Commentary: To band or not to band-is that really the question?}

\author{
S. Adil Husain, MD
}

Surgical repair of complete atrioventricular septal defect (AVSD) provides a unique technical challenge for congenital heart surgeons. Approaches and timing for repair form the basis of significant discussion among care providers. Described approaches regarding number of patches to employ and how best to divide and reconstruct the atrioventricular valves are numerous. In addition, the challenge of timing for complete repair when considering the need to address symptomatology versus the concerns for valve tissue fragility, especially within the neonatal period, can create decision-making dilemmas. Significant disparity exists within the

\footnotetext{
From Pediatric Cardiothoracic Surgery, University of Utah Health, and Heart Center, Primary Children's Hospital, Salt Lake City, Utah.

Disclosures: The author reported no conflicts of interest.

The Journal policy requires editors and reviewers to disclose conflicts of interest and to decline handling or reviewing manuscripts for which they may have a conflict of interest. The editors and reviewers of this article have no conflicts of interest.

Received for publication Aug 26, 2020; revisions received Aug 26, 2020; accepted for publication Aug 27, 2020; available ahead of print Aug 31, 2020.

Address for reprints: S. Adil Husain, MD, Heart Center, Primary Children's Hospital, 100 North Mario Capecchi Dr, Ste 2200, Salt Lake City, UT 84113 (E-mail: adil. husain@hsc.utah.edu).

J Thorac Cardiovasc Surg 2021;161:1603-4

$0022-5223 / \$ 36.00$

Copyright (c) 2020 by The American Association for Thoracic Surgery

https://doi.org/10.1016/j.jtcvs.2020.08.087
}

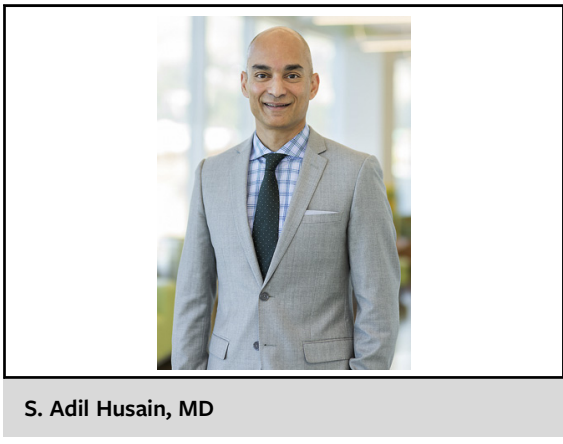

CENTRAL MESSAGE

Comparing outcomes in staged

versus early complete repair for complete atrioventricular septal defects is most impacted by the inter-stage course for patients receiving a pulmonary artery band.

literature in regards to outcomes for early primary complete repair. $^{1,2}$

Buratto and colleagues ${ }^{3}$ from Royal Children's Hospital in Melbourne, Australia, present an insightful manuscript describing their single institutional experience with early surgical intervention for complete AVSD in patients younger than 3 months of age. In a study cohort of 194 patients, $151(77.8 \%)$ underwent primary complete repair, whereas $43(22.2 \%)$ underwent initial placement of a 